\title{
A InternaÇÃo PsiQuiátrica COMPUlsória dO Psicopata EM Sede dA AÇÃo de INTERDiÇÃO:UM ESTUDO INTERDISCIPLINAR ENTRE A PSIQUIATRIA, A PSICOLOGIA E O DIREITO PROCESSUAL
}

\author{
Elaine Harzheim Macedo* \\ Fábio de Holanda Monteiro**
}

\begin{abstract}
1 Introdução. 2 Do transtorno da personalidade. 3 Do transtorno da personalidade psicopática. 4 Da internação psiquiátrica compulsória. 5 Da interdição. $6 \mathrm{Da}$ (im)possibilidade da internação psiquiátrica compulsória do psicopata em sede da ação de interdição. 7 Considerações finais. Referências.
\end{abstract}

\section{RESUMO}

O presente estudo tem como objetivo tecer algumas considerações acerca da ação de interdição e da internação psiquiátrica compulsória do psicopata. Tal estudo, de caráter interdisciplinar, mostra-se relevante não somente para os profissionais do Direito como um todo, mas também para outras áreas do conhecimento humano, como a Medicina e a Psicologia. Conquanto não se encontre prevista expressamente no ordenamento jurídico, a possibilidade do internamento por decisão judicial em sede de ação de interdição, em casos de psicopatia, deve ter seu cabimento verificado por meio de uma interpretação sistemática, de acordo com as peculiaridades de cada caso, tendo como norte o princípio da dignidade da pessoa humana.

Palavras-chave: Psicopata. Internação Psiquiátrica Compulsória. Ação de Interdição. Continência entre Pedidos.

* Possui graduação em Direito pela Universidade do Vale do Rio dos Sinos (1972), especialização (1990), mestrado em Direito pela Pontifícia Universidade Católica do Rio Grande do Sul (1997) e doutorado em Direito pela Universidade do Vale do Rio dos Sinos (2003). Professora catedrática adjunta, permanente, da Pontifícia Universidade Católica do Rio Grande do Sul. E-mail: <elaine@fhm.adv.br>.

** Mestre em Direito pela Pontifícia Universidade Católica do Rio Grande do Sul (PUCRS). Especialista em Processo Administrativo pela Universidade Federal do Ceará (UFC). Especialista em Direito Tributário pela Universidade Estadual do Ceará (UECE). Graduação em Direito pela Universidade Estadual do Piauí ( UESPI). Graduação em Engenharia Civil pela Universidade Federal do Piauí (UFPI). Professor Efetivo do Curso de Direito da Universidade Estadual do Piauí (UESPI).Procurador do Estado do Piauí. E-mail: < fabiodeh@terra.com.br>. 


\section{INTRODUÇÃO}

A psicopatia, que sempre tem despertado interesse, e certo fascínio, nos apreciadores da sétima arte, por meio de personagens como Hannibal Lecter $(\mathrm{O}$ Silêncio dos Inocentes), ${ }^{1}$ Patrick Bateman (Psicopata Americano), ${ }^{2}$ Catherine Tramell (Instinto Selvagem), ${ }^{3}$ também tem chamado a atenção da sociedade, precipuamente pelos crimes bárbaros praticados por psicopatas, não somente no exterior, ${ }^{4}$ mas também no Brasil. ${ }^{5}$

Ao contrário do comumente pensado, psicopata não é somente o indivíduo que comete crimes que provocam grande repulsa. Ele se faz presente em diversos setores da sociedade, vivendo de forma aparentemente normal no meio em que convive, exercendo profissões diversas, como médico, advogado, engenheiro, professor, servidor público, bem como no meio político, agindo de maneira dissimulada e manipuladora, sem empatia e incapaz de sentir remorso.

No presente estudo, são tecidas inicialmente considerações acerca do transtorno da personalidade, estabelecendo seu conceito e a diferença em relação ao transtorno mental, mediante aportes da Psicologia e da Medicina. Em seguida, são apontadas as principais características reveladoras da personalidade psicopática, diferenciando-a do transtorno mental. Por fim, aborda-se a possibilidade do cabimento, ou não, da ação de interdição para a internação psiquiátrica compulsória do psicopata.

O tema mostra-se relevante não somente em função dos casos específicos apresentados ao Judiciário brasileiro, cuja importância deve ser observada não apenas na realização dos julgamentos, mas também, posteriormente, na apreciação do destino a ser dado ao portador de personalidade psicopática, que, como ser humano que é, deve ter sua dignidade preservada.

\section{DO TRANSTORNO DA PERSONALIDADE}

O conceito de personalidade, ${ }^{6}$ como conjunto de características relativamente estáveis de um indivíduo, é possivelmente tão antigo quanto a ideia de humanidade. Na Grécia Antiga, há que se destacar a obra Os Carateres, por meio da qual é apresentada a primeira tentativa de tipologia da personalidade conhecida, escrita por Tirtamo de Lesbos (372 a.C. - 288 a.C), denominado Teofrasto "('o que tem o dom divino no uso das palavras')".?

Em um sentido amplo, a personalidade diz respeito às características que marcam a forma de ser da pessoa, distinguindo-a das demais, ou seja, toda pessoa tem características afetivas e comportamentais que lhe são peculiares. ${ }^{8}$

Do ponto de vista jurídico, a personalidade refere-se à aptidão que o indivíduo possui para ser sujeito de direito, assumindo direitos e obrigações. ${ }^{9}$

No campo psicológico, a personalidade tem sua origem na "combinação entre características genéticas ou geneticamente determinadas e a interação do indivíduo com o meio ambiente." Dessa forma, a etiologia dos transtornos 
de personalidade (TPs) deve levar em consideração tanto os aspectos internos quanto os aspectos externos em relação ao seu portador. ${ }^{10}$

Em psiquiatria forense, os TPs são considerados uma forma de perturbação mental. Sua apresentação, nem sempre óbvia, pode passar despercebida por leigos, culminando com a manutenção de muitos de seus possuidores em prisões, sem a devida atenção. ${ }^{11}$ Podem ser definidos como desvios graves do comportamento não acompanhados de delírios, alucinações ou "desordens significativas do comportamento." 12

A delimitação entre as personalidades normais e anormais nem sempre é fácil. Uma personalidade tida como normal em um determinado meio pode não ser noutro. ${ }^{13}$

Para Dias Cordeiro, a noção de normalidade está habitualmente associada à capacidade de a pessoa adaptar-se a situações diversas sem que haja perda da identidade. Sobredito autor acentua que os indivíduos detentores de desordens de personalidade possuem uma maior rigidez e menor flexibilidade na maneira de experimentarem e responderem em diferentes contextos sociais. ${ }^{14}$

Nessa esteira, de acordo com as ponderações de Elias Abdalla-Filho e Wolfram Engelhart, para que determinadas características possam configurar um quadro de transtorno de personalidade, faz-se necessário que tenham "caráter de inflexibilidade e desajuste à realidade, provocando um comprometimento do funcionamento do indivíduo nos mais diversos planos da vida, como o social e o interpessoal." Por conseguinte, alterações momentâneas ou passageiras do aludido funcionamento não se fazem suficientes para comporem um quadro de transtorno de personalidade. ${ }^{15}$

O transtorno da personalidade é tratado pela Organização Mundial de Saúde (OMS) por meio do título transtornos da personalidade e de comportamentos de sua Classificação Internacional das Doenças (CID-10), tendo suas especificações nos títulos F60 - F69:

Esses tipos de condição abrangem padrões de comportamento profundamente arraigados e permanentes, manifestando-se como respostas inflexíveis a uma ampla série de situações pessoais e sociais. Eles representam desvios extremos ou significativos do modo como o indivíduo médio, em uma dada cultura, percebe, pensa, sente e, particularmente, se relaciona com os outros. ${ }^{16}$

O Manual Diagnóstico e Estatístico de Transtornos Mentais (DSM-5), da Associação Americana de Psiquiatria, por sua vez, define o transtorno de personalidade como sendo

[...] um padrão persistente de experiência interna e comportamento que se desvia acentuadamente das experiências da cultura do indivíduo, é difuso e inflexível, começa na adolescência ou no início da fase adulta, é estável ao longo do tempo e leva a sofrimento ou prejuízo. ${ }^{17}$ 
Depreende-se, pois, que o transtorno da personalidade, diferentemente da doença mental (que surge, que aparece), é caracterizado como uma maneira problemática de ser, constante e perene. ${ }^{18}$

\section{DO TRANSTORNO DA PERSONALIDADE PSICOPÁTICA}

O termo psicopata constitui o "nome antigo para um indivíduo com transtorno da personalidade antissocial." ${ }^{19}$ Psicopatia, por sua vez, é o termo geral utilizado para doenças e transtornos mentais ${ }^{20}$ significando "psiquicamente doente." ${ }^{21}$

Maneira geral, o termo psicopatia - recorrente entre leigos e especialistas no assunto -, sofreu evolução à medida que surgiram novas descobertas. Uns preferem o uso da expressão psicopata; outros, sociopatia, personalidade psicopática, condutopatia, ou transtorno de personalidade antissocial. ${ }^{22}$

Discordando do sentido etimológico conferido ao termo psicopatia, Guido Palomba adota a expressão condutopatia:

[...] condutopatia é uma palavra composta por sufixação (conduta + páthos, moléstia), com vogal de ligação (conduta + o + patia). Como o nome diz, é própria dos que apresentam distúrbios de comportamento, ou seja, páthos está na conduta. ${ }^{23}$

Para fins do presente estudo, e considerando a existência das concepções diversas citadas, serão adotadas como sinônimas as expressões psicopata/ sociopata, psicopatia/sociopatia, personalidade sociopática/personalidade psicopática, condutopatia/transtorno de personalidade antissocial e transtorno de personalidade dissocial.

Os primeiros registros sobre descrições de comportamento de personalidades psicopáticas foram realizados por Girolano Cardamo, professor de Medicina italiano que viveu por volta de 1500. Cardamo, cujo filho foi decapitado por ter envenenado a própria mãe com raízes venenosas, fala pela primeira vez em "improbidade", uma situação que não chegava à total insanidade, visto que as pessoas que dela padeciam ainda conseguiam manter a aptidão para dirigir sua vontade. ${ }^{24}$

Guido Palomba acentua, porém, ter sido Pinel, em 1809, o primeiro a reunir a condutopatia (a loucura dos atos) em uma entidade clínica definida, com a expressão mania sem delírio. ${ }^{25}$ Para o autor, foi nos últimos vinte anos do século passado que o nome psicopatia começou a ser substituído por outros, dentre os quais transtorno do caráter, distúrbio do comportamento, distúrbio de conduta e sociopatia. Com o surgimento dos grandes sistemas de classificação, apareceram transtornos de personalidade e de comportamento em adultos (CID-10) e transtorno de personalidade (DSM-IV). ${ }^{26}$

Contudo, foi Hervey Cleckey, por meio de seu livro The mask of sanity, publicado em 1941, o primeiro a fornecer uma visão detalhada da psicopatia. 
Referido livro teve grande influência sobre os pesquisadores dos Estados Unidos e do Canadá, além de fornecer a estrutura clínica de muitas pesquisas sobre psicopatia feitas nos últimos vinte e cinco anos. ${ }^{27}$

Robert Hare destaca ter sido Cleckley quem estabeleceu os mais minuciosos relatos clínicos sobre a psicopatia e suas manifestações, resumindo seus principais aspectos:

[...] encanto superficial e boa inteligência; ausência de delírio e outros sinais de pensamento irracional; ausência de "nervosismo" ou manifestações neuróticas; irresponsabilidade; mentira e insinceridade; falta de remorso ou vergonha, comportamento antissocial sem constrangimento aparente; senso crítico falho e deficiência na capacidade de aprender pela experiência; egocentrismo patológico e incapacidade de amar; pobreza geral de reações afetivas; perda da capacidade de discernimento, indiferença em relações interpessoais gerais; comportamento extravagante e desagradável com bebidas alcoólicas e às vezes sem bebida; ameaças de suicídio raramente levadas a efeito; vida sexual impessoal, trivial e pobremente integrada; dificuldade de seguir qualquer plano de vida. ${ }^{28}$

A Classificação Internacional de Doenças (CID-10) da ONU, sob a terminologia transtorno de personalidade antissocial, caracteriza a personalidade psicopática por:

[...] indiferença aos sentimentos alheios; atitude flagrante e persistente de irresponsabilidade e de desrespeito a normas, regras e obrigações sociais; incapacidade de manter relacionamentos; baixa tolerância à frustração e baixo limiar para descarga de agressão; incapacidade de experimentar culpa e de aprender com a experiência; propensão para culpar os outros. ${ }^{29}$

O Manual Diagnóstico e Estatístico de Transtornos Mentais (DSM-V) da Associação Psiquiátrica Americana (APA), igualmente sob a terminologia de transtorno da personalidade antissocial, apresenta as seguintes características:

[...] fracasso em ajustar-se às normas sociais relativas a comportamentos legais, conforme indicado pela repetição de atos que constituem motivos de detenção; tendência à falsidade, conforme indicado por mentiras repetidas, uso de nomes falsos ou de trapaça para ganho ou prazer pessoal; impulsividade ou fracasso em fazer planos para o futuro; irritabilidade e agressividade, conforme indicado por repetidas lutas corporais ou agressões físicas; descaso pela segurança de si e dos outros; irresponsabilidade reiterada, conforme indicado por falha repetida em manter uma conduta consistente no trabalho ou honrar obrigações financeiras; ausência de remorso, conforme indicado pela indiferença ou racionalização em relação a ter ferido, maltratado ou roubado outras pessoas. ${ }^{30}$

Além dos caracteres acima elencados, pode-se apontar como característica essencial do transtorno da personalidade psicopática "uma inclinação natural 
e persistente de desrespeito e violação dos direitos dos outros", cujo início se dá na infância ou no começo da adolescência, continuando na idade adulta. $\mathrm{O}$ engodo e a manipulação figuram entre seus aspectos centrais, havendo, além da violação dos direitos básicos ou sentimentos alheios, contravenção de normas e regras sociais relevantes. ${ }^{31}$ Tal personalidade se revela como um padrão difuso de indiferença e de violação dos direitos dos outros. ${ }^{32}$

Hermano Tavares e Renata Ferraz, ao seu turno, apontam que as características mais evidentes do portador da personalidade psicopática são as "violações recorrentes de normas sociais, incluindo mentiras, furtos, vadiagem, inconsistência no trabalho e condutas irresponsáveis que expõem terceiros a riscos desnecessários, ou expõem a si mesmos." 33

Partindo da observação das características interpessoais, Robert Hare afirma que os psicopatas se apresentam como indivíduos "presunçosos, arrogantes, insensíveis, dominantes, superficiais e manipuladores." Destaca que se mostram - quando da manifestação de seus afetos -, irritáveis, incapazes de estabelecer fortes vínculos emocionais, desprovidos de empatia, sentimento de culpa ou remorso. Para Hare, os traços interpessoais e afetivos desses indivíduos se associam a um estilo de vida desviado socialmente, incluindo comportamentos irresponsáveis e impulsivos, com uma tendência a ignorar ou violar as convenções e normas sociais. ${ }^{34}$

Odon Ramos Maranhão, por sua vez, ressalta que os psicopatas se mostram incapazes de aprenderem pela experiência, integrarem grupos e efetivarem um plano de vida, fazendo-se crer que já nascem com um "defeito impediente do aproveitamento da experiência vivida". Tais indivíduos, de acordo com o autor, não são mal formados, mas sim mal constituídos. ${ }^{35}$

Para Guido Palomba, a psicopatia apresenta-se como "uma perturbação da saúde mental que se caracteriza por transtornos de conduta, ou seja, a deformidade do indivíduo está no comportamento anormal." Acentua que não configura propriamente uma doença mental, posto esta pressupor ruptura com a realidade. Ressalta, porém, que este fica na "zona fronteiriça" entre a doença mental e a normalidade. ${ }^{36}$

No mesmo lanço, a explanação de J. Alves Garcia, para quem a psicopatia se apresenta como uma "enfermidade fronteiriça ou pronunciada da personalidade", estruturada de forma precoce, desde a infância e a juventude, e caracterizada pela anormalidade dos instintos e da conduta. ${ }^{37}$

Assim, é de ter-se como normais situações cujas regras são ocasionalmente quebradas pelas pessoas, posto serem as regras que ajudam a manter ordem social, protegendo-as de possíveis danos ocasionados por transgressões. Ao contrário, quando, desde a infância, há insurgência contra qualquer tipo de regulamento, mesmo com todas as sanções, como o castigo parental, o ostracismo, o fracasso ou a prisão, permanecendo em mau comportamento, resistindo a qualquer regramento ou autoridade, tem-se o indivíduo portador da personalidade psico- 
pática. Tal indivíduo, sem esforço algum, resiste a todo e qualquer regramento, "incapaz de ver além de seu próprio egoísmo ou de adotar padrões corretos." 38 Não obstante isso, é de ser relevado que nem toda a pessoa que comete atos antissociais de forma isolada é portadora de personalidade psicopática. No entanto, todo indivíduo portador de personalidade psicopática apresenta uma extensa gama de comportamentos antissociais. ${ }^{39}$

\section{DA INTERNAÇÃO PSIQUIÁTRICA COMPULSÓRIA}

A internação psiquiátrica é tratada pelo ordenamento jurídico brasileiro nos arts. $4^{\circ}, 6^{\circ}, 7^{\circ}, 8^{\circ}$ e $9^{\circ}$, da Lei $n^{\circ} 10.216 / 2001$, a assim chamada Lei da Reforma Psiquiátrica - LRP. ${ }^{40}$

Consoante o disposto no art. $4^{\mathrm{o}}$, caput, da referida Lei, ${ }^{41}$ a internação psiquiátrica, seja qual for sua modalidade, somente será cabível quando os recursos extra-hospitalares forem considerados insuficientes, com risco à integridade física, à saúde ou à vida dos portadores de transtornos mentais ou a terceiros. ${ }^{42}$

A situação de perigo concreto deve estar prevista em laudo médico circunstanciado, caso contrário, torna-se incabível a obrigatoriedade da internação. ${ }^{43}$ Havendo necessidade de internamento, este deverá buscar a cessação do estado de perigo, com consequente reinserção social do paciente em seu meio. ${ }^{44}$

$\mathrm{O}$ art. $6^{\circ}$, incs. I, II e III, traz como modalidades de internação a voluntária, a involuntária e a compulsória. ${ }^{45}$ A voluntária dá-se com o consentimento do paciente, que deverá assinar uma declaração atestando sua escolha pelo tratamento. ${ }^{46}$ Pressupõe, portanto, a plena capacidade civil do interno. A involuntária ocorre sem a autorização do interno e a pedido de terceiro, com seu término se dando por solicitação escrita do familiar ou do responsável legal, ou ainda quando houver manifestação do médico responsável pelo tratamento. ${ }^{47}$ Pressupõe, por parte do requerente, legitimidade para a postulação. Já a compulsória é proveniente de ordem judicial. ${ }^{48}$

Consoante Carrasco Gómez, os internamentos involuntários (pela LRP, involuntário e compulsório) são todos aqueles levados a efeito pela decisão de outras pessoas que não o interessado (terceiros ou ordem judicial), sem seu consentimento ou mesmo com oposição, passiva ou ativa.$^{49}$ Devem ocorrer quando os recursos extra-hospitalares não forem suficientes e houver risco à integridade física, à saúde ou à vida do portador de transtorno mental ou a terceiros. ${ }^{50}$

O internamento do portador de transtorno mental, normalmente, dá-se quando oferece riscos para si, para a família ou para terceiros, ou ainda quando houver maiores dificuldades na formação de um diagnóstico adequado em uma unidade de tratamento ambulatorial (extra-hospitalar). Em determinadas situações, independentemente da "patologia de base", a pessoa pode apresentar risco agudo de suicídio, ocasião em que a internação surge como o meio mais viável para um maior controle e auxílio terapêutico. ${ }^{51}$ 
Quando uma pessoa é portadora de transtorno mental, há o risco - dada à perda de controle dos impulsos e da capacidade de julgamento apropriado da realidade -, do cometimento de atitudes que causem danos a si que podem inclusive, após sua recuperação, deixar-lhe marcas duradouras, como o estigma de uma pessoa doente mental. Assim, uma das finalidades da internação compulsória é a de afastar, momentaneamente, uma pessoa que está padecendo de sofrimento psíquico do meio em que vive, para que seja preservada sua integridade como sujeito de uma sociedade que lhe atribui determinado valor. ${ }^{52}$

Enquanto as duas primeiras formas de provocação da internação operam-se no âmbito extrajudicial, a internação compulsória judicial reclama via adequada para a invocação da prestação judicial pretendida, e, no particular, a Lei n. 10.216/2010 é omissa, deixando um vazio a ser preenchido hermeneuticamente. Neste artigo, enfrenta-se parcialmente essa omissão, por intermédio da ação de interdição.

\section{DA INTERDIÇÃO CIVIL}

A interdição é ação jurisdicional pela qual se busca a decretação de que determinada pessoa é parcial ou totalmente incapaz de praticar os atos da vida civil, em função da perda de discernimento para a condução de seus próprios interesses, agregando-se o efeito constitutivo de nomeação de representante legal - o curador -, ao interditado..$^{53} \mathrm{~A}$ decretação de incapacidade civil pode ser total ou relativa. A total se dá quando o interdito é absolutamente incapaz de exercer pessoalmente os atos da vida civil. ${ }^{54} \mathrm{~A}$ relativa dá-se quando o interdito é incapaz de exercer certos atos da vida civil..$^{55}$

Segundo o art. 1.767, incs. I e III, do CC/2002, ${ }^{56}$ podem ser interditados aqueles que, por causa transitória ou permanente, não puderem exprimir sua vontade; os ébrios habituais e os viciados em tóxico. Por meio da interdição, submete-se à curatela "o maior que passou a não ter mais discernimento para reger sua pessoa e bens." ${ }^{57}$ Eventualmente, o relativamente capaz, por força da idade, em sendo acometido de incapacidade por enfermidade que lhe retire o discernimento para a prática de atos da vida civil (art. $3^{\circ}$, inciso II, CC/2002), será também submetido à curatela, já que a tutela - meio legal de assistência -, não supre a representação por incapacidade absoluta.

Os que, por causa transitória ou permanente, não puderem exprimir sua vontade, assim como os ébrios habituais e os viciados em tóxico, de acordo com o art. $4^{\circ}$, incs. I a IV, do CC/2002, são reputados como relativamente incapazes de exercerem seus atos. ${ }^{58}$

A lista dos relativamente incapazes acima referida é resultante das modificações impostas pela Lei no 13.146/15, de 6 de julho de 2015, o Estatuto da Pessoa com Deficiência - EPD, o qual desvincula, expressamente, a incapacidade da deficiência ou do desenvolvimento mental incompleto, reportando-se tão somente à impossibilidade de exprimir a vontade. ${ }^{59}$ 
É ser relevado que a atual redação conferida ao art. $4^{\circ}$ do CC/2002 deu origem a uma nova teoria das incapacidades na medida em que a pessoa com deficiência não pode ser tida como incapaz pelo simples fato de ser portadora de alguma deficiência. Houve, com isso, um desatrelamento dos conceitos de incapacidade e de pessoa com deficiência, não mais existindo uma "relação implicacional entre a deficiência (física, mental ou intelectual) e a incapacidade para os atos da vida civil." A pessoa com deficiência, vale ressaltar, pode não sofrer qualquer restrição quanto à possibilidade de manifestar suas vontades e suas preferências. As causas de incapacidade relativa foram objetivadas, afastando indagações referentes ao estado mental do indivíduo. $\mathrm{O}$ simples fato de possuir deficiência física, mental ou intelectual não é, por si só, motivo ensejador da incapacidade civil. ${ }^{60}$ Assim, o mero fato de o indivíduo ser portador de transtorno mental não faz dele automaticamente um incapaz.

Não se pode perder de vista, contudo, que a mudança apontada não implica que o portador de transtorno mental não possa vir a ter a sua capacidade limitada para a prática de certos atos. Permanece a possibilidade de que venha submeter-se à curatela. $\mathrm{O}$ que se afasta, nos termos do Estatuto da Pessoa com Deficiência, frisa-se, é a sua condição de totalmente incapaz. ${ }^{61}$

Nessa esteira, a explanação de Cristiano Farias e Nelson Rosenvald, para os quais a incapacidade relativa decorrente de causa psicológica (transtorno mental) clama pelo reconhecimento por via judicial por meio de uma ação de curatela (ação de interdição). ${ }^{62}$

O tratamento do incapaz, que resulta da presunção da falta de discernimento ou compreensão, mostra-se imperfeito e impreciso para o tratamento de atos patrimoniais, uma vez que transmite as suas realizações

[...] à vontade de um representante ou assistente, assim como assemelha em categorias genéricas como a de deficiente mental, o paranóico, o portador de síndrome de Down ou de Alzheimer entre outros, desconsiderando a diferença entre tais indivíduos. ${ }^{63}$

Tem-se, assim, e de acordo com os arts. $4^{\circ}$, III e 1.767, I, do CC/2002, ${ }^{64}$ que podem ser submetidos à curatela, por meio da interdição, os que não puderem exprimir sua vontade por causa transitória ou permanente (causa psicológica).

O fato que mais revela os objetivos desse estudo é que a ação de interdição não tem, pelo menos em princípio, compromisso com o tratamento do interditando, visando à solução de uma questão de ordem civil (assistência/ representação civil) por meio da nomeação de curador (seja a interdição total ou parcial), transmitindo, aí, sim, à lei civil e processual a responsabilidade pelos cuidados necessários ao interdito, ao curador nomeado, que disso deverá prestar contas judiciais. Nesse sentido, o art. 759 do CPC/2015: o curador deverá buscar tratamento e apoio apropriado à conquista da autonomia do interdito. 


\section{DA (IM) POSSIBILIDADE DA INTERNAÇÃO PSIQUIÁTICA COM- PULSÓRIA DO PSICOPATA EM SEDE DA AÇÃO DE INTERDIÇÃO}

Observadas as previsões legais em que a pessoa maior de 18 (dezoito) anos pode ficar sujeita à curatela, ${ }^{65}$ interessa, aqui, verificar a possibilidade, ou não, acerca do cabimento da ação de interdição como meio válido para a internação psiquiátrica compulsória do psicopata.

$\mathrm{O}$ art. 1.767, I, do CC/2002, ${ }^{66}$ inclui entre os que estão sujeitos à curatela aqueles que, por causa transitória ou permanente, não puderem exprimir sua vontade. Com isso, tem-se que, enquanto perdurar a causa transitória ou permanente que impeça a manifestação de vontade, a pessoa será tida como relativamente incapaz. Em desaparecendo a causa, a capacidade é restabelecida.

A ação de interdição ${ }^{67}$ encontra-se disciplinada nos arts. 747 a 758 do Código de Processo Civil (CPC). Reconhecida judicialmente a impossibilidade de expressão da vontade (autogoverno), para todos ou para parte dos atos da vida civil, a consequência é a designação de um curador para fins de proteção do patrimônio e dos interesses do portador de transtorno psíquico ${ }^{68}$ Os legitimados para propô-la encontram-se discriminados nos incisos I a IV do art. 747: o cônjuge ou companheiro; os parentes ou tutores; o representante em que se encontra abrigado o interditando; e o Ministério Público. ${ }^{69}$

Para o presente estudo, será levada a efeito a interdição promovida pelo Ministério Público, posto que, nas situações que envolvem a internação psiquiátrica compulsória do psicopata, têm sido mais comum as ações perpetradas por referido Orgão. ${ }^{70}$

$\mathrm{O}$ art. 748 , incs. I e II, do CPC, ${ }^{71}$ preceitua que o Ministério Público somente promoverá a interdição em caso de doença mental grave: se as pessoas designadas nos incisos I, II e III do art. 747 não existirem ou não promoverem a interdição; se, existindo, forem incapazes as pessoas mencionadas nos incisos I e II do art. $747 . .^{72}$

Ocorre que, em não sendo o transtorno da personalidade psicopática reconhecido como uma doença mental grave, é de se indagar se é possível o Ministério Público propor ação de interdição para o internamento compulsório do indivíduo por ele acometido?

A legitimação ativa do Ministério Público, para requerer a ação de interdição, na redação do art. 1.178, I, II e III, do CPC/1973, ${ }^{73}$ ocorria nas seguintes situações: no caso de anomalia psíquica; se não existir ou não promover a interdição de algumas das pessoas designadas no artigo antecedente, ns. I e II ${ }^{74}$ se, existindo, forem menores ou incapazes.

Em comentários ao inciso I do art. 1.178 do CPC/1973, Costa Machado ressalta que, diferentemente do CC/2002 (com redação anterior à Lei n. 13.146, de 06.07.2015), que se refere à hipótese de "doença mental grave"75 como "autorizadora da iniciativa ministerial", o dispositivo em referência traz 
a expressão "anomalia psíquica”.Para aludido autor, a locução "anomalia psíquica" mostra-se abrangente tanto quanto doença mental grave, de forma que se pode concluir que

[...] o Ministério Público pode promover a interdição, em defesa da sociedade, em todos os casos de enfermidade, doença, alienação mental, loucura de qualquer espécie, psicopatia ou como quer que se denomine a anomalia psíquica, desde que grave $\left[\ldots . .{ }^{76}\right.$

O pensamento acima é corroborado por Célia Abreu, para quem

As causas determinantes da incapacidade civil poderão ser transtornos de personalidade, transtornos de humor, transtornos mentais, deficiências físicas, psíquicas ou funcionais, problemas graves de saúde no sentido mais amplo e que impeçam o sujeito de exprimir sua manifestação volitiva, com o comprometimento de sua autonomia. ${ }^{77}$

Estando os transtornos da personalidade entre aqueles determinantes da incapacidade civil, é de ter-se que o psicopata está sujeito à ação de interdição, de acordo com as circunstâncias de cada caso concreto.

Além do mais, não permitir a propositura da ação de interdição ao Ministério Público para fins de internamento compulsório do psicopata e permitir para o portador de transtorno mental grave configura não somente agressão ao princípio da proporcionalidade (que invoca uma medida necessária, adequada e proporcional), mas também ao princípio da dignidade da pessoa humana (art. $1^{\mathrm{o}}, \mathrm{III}, \mathrm{CF} / 88$ ), posto terminar por conferir tratamento discriminatório entre o doente mental grave e o psicopata. Isso sem falar que o termo doença mental grave demanda discussões, posto a Psiquiatria encontrar-se em constante evolução no tratamento para o firmamento do diagnóstico e do prognóstico dos transtornos da mente. ${ }^{78}$

Não obstante isso, não se pode olvidar que não existe uma lista de quais enfermidades mentais são passíveis do uso da medida de internamento compulsivo pelas seguintes razões: a medida é de índole legal e se baseia na falta de capacidade de decisão de um sujeito em concreto, independentemente dos termos médicos-sanitários em que se defina sua patologia; a elaboração de uma lista limitaria a aplicação da medida; pode haver erros ou mudanças de diagnósticos; uma das características da Medicina é sua contínua evolução e podem surgir novas enfermidades nas quais a medida é aplicável. ${ }^{79}$

Como pontuado por Célia Abreu, a CF/88, ao escolher a dignidade humana como fundamento, ${ }^{80} \mathrm{com}$ o objetivo fundamental de erradicação da pobreza e da marginalização, e de redução das desigualdades sociais, ${ }^{81}$ além do previsto no $\S 2^{\circ}$ do art. $5^{\circ}, 82$ no sentido de não exclusão de quaisquer direitos ou garantias, desde que provenientes de princípios constitucionalmente adotados, estabelece a consagração de uma verdadeira "cláusula geral de tutela e promoção da pessoa humana", sendo esta o valor máximo do ordenamento jurídico. ${ }^{83}$ 
Para sobredita autora,

No caso do psicopata, se tem alguém que põe em risco seus direitos fundamentais, mas também os daqueles com quem convive, fora os da sociedade, como um todo. Surge, então, como uma pessoa que é tida como penalmente responsável por seus atos e, segundo boa parte da psiquiatria, não é exatamente um portador de transtorno mental, mas é, em si mesmo, alguém com personalidade "vulnerável," por sua própria condição. ${ }^{84}$

Não se pode deixar de observar ainda que a ordem jurídica constitucional brasileira não admite qualquer forma de tratamento anti-isonômico, posto que a autonomia de cada ser humano deve ser

[...] considerada em abstrato, como sendo a capacidade potencial que cada ser humano tem de autodeterminar sua conduta, não dependendo da sua efetiva realização no caso da pessoa em concreto, de tal sorte que o absolutamente incapaz (por exemplo, o portador de grave deficiência mental) possui exatamente a mesma dignidade que qualquer outro ser humano física e mentalmente capaz. ${ }^{85}$

José G. V. Taborda aponta que devem ser observados os seguintes requisitos para a ocorrência da internação psiquiátrica compulsória: presença de transtorno mental; risco de autoagressão; risco de heteroagressão à pessoa difusa ou determinada; risco de agressão à ordem pública; risco de exposição social; e incapacidade de autocuidados. ${ }^{86}$

Da lição acima, infere-se que, se um indivíduo possui risco de cometer agressão a si ou a terceiros, sem capacidade de se autogovernar, de se autocuidar ou de agredir a ordem pública, tais situações, por si só, podem dar ensejo à internação compulsória. Incorrendo o psicopata em tais requisitos, ainda que não seja tido como portador de transtorno mental grave, em si, há de ser internado compulsoriamente, visto que o uso de tal medida visa precipuamente ao seu bem-estar e a sua proteção, bem como a proteção da sociedade.

O "caráter irrenunciável do princípio da dignidade da pessoa humana" traz como consequência, fora outras, a obrigatoriedade de o Estado proteger o indivíduo contra ele mesmo, caso se faça necessário. ${ }^{87}$ Dessa forma, a internação compulsória surge como medida protetiva do psicopata não somente em relação a atos praticados contra os outros, mas contra si mesmo.

O princípio da dignidade da pessoa humana (art. $1^{\circ}$, III, CF/88) é incompatível com uma "abstrata homogeneização dos seres humanos em uma categoria despersonalizada de incapacidades." Daí a sentença de curatela ter que levar em consideração os aspectos pessoais, individualizados, de cada pessoa. ${ }^{88}$

Ao decidir pela interdição, o magistrado deve observar as caracterítiscas pessoais de cada indivíduo, assim como de sua condição física, psíquica e 
intelectual, a fim de que estabeleça um projeto terapêutico individualizado. ${ }^{89}$

O art. 1.767, I e III, do CC/2002 $2^{90}$ (com redação da Lei n. 13.146/2015), estabelecendo que, por causa tansitória ou permanente, os que não puderem exprimir sua vontade, como os ébrios habituais e os viciados em tóxicos estão sujeitos à curatela (interdição), não há causa jurídica para afastar a interdição sobre os portadores de persolidade psicopática, a depender das idiossincrasias de cada um.

Guido Palomba ressalta que os psicopatas são considerados aptos para a prática de alguns atos da vida civil, o que os torna relativamente incapazes. Para referido autor, "[...] são indivíduos fronteriços, nem normais, nem alienados mentais, cujos distúrbios de conduta podem muito bem vir a comprometer a administração dos próprios bens, como amiúde ocorre." ${ }^{11}$

Discorrendo especificamente sobre o inciso I do art. 1.767 do CC/2002, Ricardo Gregório afirma que este

[...] possui grande abrangência já que, qualquer causa que efetivamente impeça uma pessoa de expressar sua vontade total ou parcialmente, impossibilitando-a de gerir a própria vida e /ou os próprios bens, será levada em consideração pelo aplicador da norma. ${ }^{92}$

Na mesma toada, Célia Abreu, ao expor sobre a necessidade de flexibilização da curatela, a fim de que outros portadores de transtornos mentais (não lembrados pelo legislador) não fiquem sem a devida proteção, colocando-os em situação de risco incompatível com a posição ocupada pela pessoa na odem constitucional brasileira. ${ }^{93}$

Sobre a possibilidade do cabimento da ação da interdição para internação compulsória do portador de personalidade psicopática,,${ }^{94}$ cita-se importante julgado do Superior Tribunal de Justiça (STJ):

PROCESSUAL CIVIL. CIVIL. RECURSO ESPECIAL. INTERDIÇÃO. CURATELA. PSICOPATA. POSSIBILIDADE. 1. Ação de interdição ajuizada pelo recorrente em outubro de 2009. Agravo em recurso especial distribuído em 07/10/2011. Decisão determinando a reautuação do agravo em recurso especial publicada em 14/02/2012. Despacho determinando a realização de nova perícia psiquiátrica no recorrido publicado em 18/12/2012. 2. Recurso especial no qual se discute se pessoa que praticou atos infracionais equivalentes aos crimes tipificados no art. 121, $\S 2^{\circ}$, II, III e IV (homicídios triplamente qualificados), dos quais foram vítimas o padrasto, a mãe de criação e seu irmão de 03 (três) anos de idade, e que ostenta condição psiquiátrica descrita como transtorno não especificado da personalidade (CID 10 - F 60.9), esta sujeito à curatela, em processo de interdição promovido pelo Ministério Público Estadual. 3. A reincidência criminal, prevista pela psiquiatria forense para as hipóteses de sociopatia, é o cerne do presente debate, que não reflete apenas a situação 
do interditando, mas de todos aqueles que, diagnosticados como sociopatas, já cometeram crimes violentos. 4. A psicopatia está na zona fronteiriça entre a sanidade mental e a loucura, onde os instrumentos legais disponíveis mostram-se ineficientes, tanto para a proteção social como a própria garantia de vida digna aos sociopatas, razão pela qual deve ser buscar alternativas, dentro do arcabouço legal para, de um lado, não vulnerar as liberdades e direitos constitucionalmente assegurados a todos e, de outro turno, não deixar a sociedade refém de pessoas, hoje, incontroláveis nas suas ações, que tendem à recorrência criminosa. 5. Tanto na hipótese do apenamento quanto na medida socioeducativa - ontologicamente distintas, mas intrinsecamente iguais - a repressão do Estado traduzida no encarceramento ou na internação dos sociopatas criminosos, apenas postergam a questão quanto à exposição da sociedade e do próprio sociopata à violência produzida por ele mesmo, que provavelmente, em algum outro momento, será replicada, pois na atual evolução das ciências médicas não há controle medicamentoso ou terapêutico para essas pessoas. 6. A possibilidade de interdição de sociopatas que já cometeram crimes violentos deve ser analisada sob o mesmo enfoque que a legislação dá à possibilidade de interdição - ainda que parcial - dos deficientes mentais, ébrios habituais e os viciados em tóxicos (art. 1767, III, do CC-02). 7. Em todas essas situações, o indivíduo tem sua capacidade civil crispada, de maneira súbita e incontrolável, com riscos para si, que extrapolam o universo da patrimonialidade e que podem atingir até a sua própria integridade física sendo também ratio não expressa, desse excerto legal, a segurança do grupo social, mormente na hipótese de reconhecida violência daqueles acometidos por uma das hipóteses anteriormente descritas, tanto assim, que, não raras vezes, sucede à interdição, pedido de internação compulsória. 8. Com igual motivação, a medida da capacidade civil, em hipóteses excepcionais, não pode ser ditada apenas pela mediana capacidade de realizar os atos da vida civil, mas, antes disso, deve ela ser aferida pelo risco existente nos estados crepusculares de qualquer natureza, do interditando, onde é possível se avaliar, com precisão, o potencial de auto-lesividade ou de agressão aos valores sociais que o indivíduo pode manifestar, para daí se extrair sua capacidade de gerir a própria vida, isto porquê, a mente psicótica não pendula entre sanidade e demência, mas há perenidade etiológica nas ações do sociopata. 9. A apreciação da possibilidade de interdição civil, quando diz respeito à sociopatas, pede, então, medida inovadora, ação biaxial, com um eixo refletindo os interesses do interditando, suas possibilidades de inserção social e o respeito à sua dignidade pessoal, e outro com foco no coletivo - ditado pelo interesse mais primário de um grupo social: a proteção de seus componentes -, linhas que devem se entrelaçar para, na sua síntese, dizer sobre o necessário discernimento para os atos da vida civil de um sociopata que já cometeu atos de agressão que, in casu, levaram a óbito três pessoas. 10. A 
solução da querela, então, não vem com a completa abstração da análise da capacidade de discernimento do indivíduo, mas pela superposição a essa camada imediata da norma, da mediata proteção do próprio indivíduo e do grupo social no qual está inserido, posicionamento que encontrará, inevitavelmente, como indivíduo passível de interdição, o sociopata que já cometeu crime hediondo, pois aqui, as brumas da dúvida quanto à existência da patologia foram dissipadas pela violência já perpetrada pelo indivíduo. 11 . Sob esse eito, a sociopatia, quando há prévia manifestação de violência por parte do sociopata, demonstra, inelutavelmente, percepção desvirtuada das regras sociais, dos limites individuais e da dor e sofrimento alheio, condições que apesar de não infirmarem, per se, a capacidade do indivíduo gerenciar sua vida civil, por colocarem em cheque a própria vida do interditando e de outrem, autorizam a sua curatela para que ele possa ter efetivo acompanhamento psiquiátrico, de forma voluntária ou coercitiva, com ou sem restrições à liberdade, a depender do quadro mental constatado, da evolução - se houver - da patologia, ou de seu tratamento. 12. Recurso especial provido. (STJ, REsp 1.306.687 / MT, $3^{\mathrm{a}}$ T., Rel. Min. Nancy Andrighi, DJe 22/04/2014).

A decisão acima - paradigmática no âmbito do STJ - teve entendimento diverso daquele contido nas decisões de primeira e segunda instância. Em primeira instância, conquanto reconhecida a existência de alguma enfermidade, entendeu-se que a situação do interditando não se enquadrava nas hipóteses do art. 1.767 do CC/2002 $2^{95}$ (com redação anterior à Lei n.13.146/2015) e que a enfermidade existente não retira o discernimento para os atos da vida civil, assim como não se tratava de deficiente mental. Na segunda instância, em sede de apelação, foi negado o provimento, sob o entendimento de que não houve comprovação da incapacidade do interditando para a gestão dos atos da vida civil e bens. ${ }^{96}$

Em seu voto, a Ministra Relatora ressalta que, embora os instrumentos legais então existentes se mostrem ineficientes para proteção da sociedade, ${ }^{97}$ bem como para a garantia de vida digna aos psicopatas (dado ao quadro de zona fronteiriça da psicopatia, entre a sanidade mental e a loucura), devem-se buscar alternativas que não vulnerem as liberdades e os direitos assegurados a todos e que não deixem a sociedade à mercê de indivíduos tidos, hodiernamente, como incontroláveis. ${ }^{98}$

A interdição dos psicopatas ${ }^{99}$ que já cometeram crimes violentos, ${ }^{100}$ de acordo com a Ministra Relatora, deve ser apreciada sob o mesmo enfoque que a legislação dá à possibilidade de interdição, mesmo que parcial, dos ébrios habituais e dos viciados em tóxicos (art. 1.767, III, CC/2002). ${ }^{101}$ Existiria, nesse caso, uma mesma linha lógica, posto que se faria presente uma capacidade passível de sofrer comprometimento em lapsos temporais, tal como ocorre com os ébrios (por ingestão abusiva de álcool) e com os toxicômanos (por uso ilegal de tóxicos). Em tais situações, ter-se-ia um indivíduo com "capacidade civil 
crispada", com riscos para si, que extrapolam o universo da patrimonialidade, podendo atingir até mesmo sua integridade física. ${ }^{102}$

Ainda de acordo com a Ministra Relatora, a decisão deve ser tida como extremamente casuísta, visto que a constatação de uma psicopatia, fixada genericamente, não atrairá, necessariamente, a interdição do sociopata. Entretanto, evidenciado pelas circunstâncias, em especial as pregressas, em que há histórico de violência e desdém às regras sociais, não há que se falar em plena capacidade do indivíduo, sujeitando este à interdição ${ }^{103} \mathrm{e}$ sua internação psiquiátrica em estabelecimento adequado.

O julgado traz que a possibilidade de interdição do psicopata requer uma "medida inovadora", que reflita tanto nos interesses do interditando e nas suas possibilidades de inserção social e no respeito à sua dignidade pessoal como no interesse coletivo (proteção de seus componentes). ${ }^{104}$

É de se ressaltar que o procedimento de interdição deve buscar o resguardo da pessoa reputada como incapaz, culminando na prolação de uma "sentença que reconheça um projeto terapêutico individualizado." A decisão judicial deverá indicar o nível de curatela a ser exercido pelo curador, apontando os atos civis sob limitação. ${ }^{105}$

No julgado acima ementado, a Ministra Relatora, mesmo constatando que a situação do psicopata não se enquadrava nas elencadas entre as do art. 1.767, I (com redação anterior à conferida pela Lei n. 13.146/2015), ${ }^{106}$ achou por bem flexibilizar a curatela total a fim de que fosse aplicada a um "indivíduo que, embora não lembrado pelo legislador, dela necessitava sob pena de colocar em perigo a si próprio e a comunidade na qual se insere."107

Sem embargo da posição doutrinária defendida - que norteou a decisão do STJ -, defende-se que há absoluta independência entre o juízo criminal e o juízo cível, nada impedindo que, a despeito de o réu ter sido reconhecido, no caso em concreto, como capaz para responder à ação criminosa, sendo criminalmente penalizado, venha, em sede de ação de interdição, ser considerado incapaz para os atos da vida civil, com nomeação de curador e, cumulativamente, com a determinação de internação compulsória, nos termos da lei de regência, com vistas à proteção de sua pessoa e de terceiros.

É de ser relevado que não se pode deixar de observar que, em termos gerais, o normal é a convivência familiar e comunitária de toda e qualquer pessoa, incluindo-se "aqueles que, por causa transitória ou permanente, não puderem exprimir sua vontade." Função disso, a internação psiquiátrica do curatelado (aqui o psicopata) por meio de ação de interdição deve ocorrer de forma excepcional, quando os recursos extra-hospitalares não se mostrarem suficientes, em observância ao disposto no art. $4^{\circ}$, caput, da Lei $\mathrm{n}^{\mathrm{O}} 10.216 / 2001^{108}$ e ao princípio da dignidade da pessoa humana (art. $1^{\circ}$, III, da CF/88). 
Como ponderado por Célia Abreu, não há mais qualquer possibilidade de a interdição remeter a ideias de confinamento ou de exclusão. Somente quando a internação se fizer útil e necessária, dentro das condições legais previstas, é que esta poderá ocorrer. ${ }^{109}$

Além disso, ainda que a internação possa ser provocada extrajudicialmente pelo curador, nos termos autorizados pela Lei 10.216/2001, em seu art. $6^{\circ}$, inciso II, combinado com o art. 758 do CPC/2015, nada impede que, no curso da interdição, em sede de tutela provisória, nos termos dos arts. 294 e 300 do Estatuto Processual, dada eventual urgência e a presença de perigo de dano ou mesmo risco ao resultado útil do processo (imagine-se um quadro psicótico de destruição ou de autodestruição), possa a internação ser provocada judicialmente.

Não se olvide que, uma vez provocada a jurisdição pela via da ação de interdição, em que a intervenção do Ministério Público é obrigatória, o valor maior a ser tutelado é o próprio interditando: sua vida, seus bens, seus interesses jurídicos. Em contrapartida, ainda que o eventual tratamento a ser dispensado ao interdito não seja objeto específico desta ação de procedimento de jurisdição voluntária, a cumulação de pedidos e de ações é expressamente autorizada pela lei processual, conforme arts. 55 e 56 do CPC/2015, que regulam a conexão e a continência das ações por força de identidade de partes, de causa de pedir e de pedido, o que não ofende o devido processo legal.

De sorte que a ação de interdição pode, sim, abarcar, por força da continência, a pretensão de internação compulsória em casos de interdição quando encontra como fundamento fático a presença de risco à saúde e à integridade física e mental do próprio interdito ou de terceiros, suficientemente demonstrada por laudos de profissionais habilitados, assumindo o Estado-juiz uma posição proativa em favor da própria dignidade da pessoa humana.

\section{CONSIDERAÇÕES FINAIS}

O crescimento dos transtornos mentais no Brasil tem, cada vez mais, levado às internações psiquiátricas compulsórias daqueles por eles acometidos. Esse aumento não se dá apenas por falha no sistema de saúde mental brasileiro, mas também pelo fato de os familiares não optarem inicialmente pela internação domiciliar, o que termina por sobrecarregar o Judiciário e as entidades hospitalares com pedido de internações compulsórias que, na maioria das vezes, mostram-se desnecessárias ou, pelo menos, que poderiam ter sido evitadas se tomadas medidas adequadas em tempo oportuno.

Em que pese não ser comum a internação compulsória do psicopata, por não ser este reconhecido como portador de enfermidade mental, em algumas situações peculiares em que seja comprovado o risco de dano a si, a terceiro e à sociedade como um todo, há de se ter como cabível a medida de internamento. 
O ordenamento jurídico nacional garante a todos, indistintamente, o direito à saúde, mesmo aos que tiverem cometido alguma infração penal e não sejam reconhecidos como portadores de transtornos mentais, como é o caso do psicopata, já que o princípio da dignidade da pessoa humana assegura a todos um tratamento digno, sem qualquer distinção ou discriminação.

Conquanto não haja norma específica reconhecendo o direito do portador de personalidade psicopática à internação psiquiátrica compulsória por meio da ação de interdição, esta se mostra cabível nas situações excepcionais em que for verificada a existência de risco à sua própria integridade, bem como à sociedade.

Mesmo cabendo ao Judiciário a determinação do internamento compulsório, devido ao fato de ser da competência do magistrado formar sua convicção de acordo com o caso concreto analisado. Não se pode deixar de observar que as peculiaridades de cada caso devem ser apreciadas quanto ao uso da medida, a fim de que sejam fixados os limites da curatela imposta ao psicopata, nada impedindo que, na ação de interdição, em princípio voltada para compor questões de ordem diversa como assistência e/ou representação do interdito para os atos da vida civil, uma vez prestando-se o processo e a jurisdição para a realização dos direitos tutelados pela ordem jurídica, cumule, em seu bojo, a pretensão maior, de proteção ao indivíduo, mediante a determinação, a pedido ou até de ofício, da internação compulsória do interdito.

\section{REFERÊNCIAS}

ABDALLA-FILHO, Elias; ENGELHARDT, Wolfram. Transtornos da personalidade. In: ABDALLA-FILHO, Elias; CHALUB, Miguel; TELLES, Lisieux E. de Borda. Psiquiatria Forense de Taborda. 3. ed. Porto Alegre: Artmed, 2016.

ABREU, Célia Barbosa. Primeiras linhas sobre interdição após o Novo Código de Processo Civil. Itu, SP: CRV, 2015.

ABREU, Célia Barbosa; VAL, Eduardo Manuel. A flexibilização da curatela do psicopata: uma interpretação constitucional pelo Superior Tribunal de Justiça. Revista da AJURI, Porto Alegre, v. 41, n. 134, p. 109-133, jun. 2014.

ABREU, Michele O. de. Da imputabilidade do psicopata. Rio de Janeiro: Lumen Juris, 2013.

AMERICAN PSYCHIATRIC ASSOCIATION. Manual diagnóstico e estatístico de transtornos mentais: DSM-5. Tradução Maria Inês Corrêa et al. Revisão Técnica Aristides Volpato Cordioli et al. 5. ed. Porto Alegre: Artmed, 2014.

BALLONE, Geraldo José. Transtornos da personalidade. In: SOUZA, José Carlos; GUIMARÃES, Liliana A. M.; BALLONE, Geraldo José (Org.). Psicopatologia e Psiquiatria básicas. 2. ed. São Paulo: Vetor, 2013. 
BRASIL. Superior Tribunal de Justiça. HC 135.271/SP, $3^{\mathrm{a}}$ T., $3^{\mathrm{a}}$, Rel. Min. Sidnei Beneti, DJe de 4 de fevereiro de 2014. Disponível em: <http://www.stj. jus.br/SCON/jurisprudência/toc.jsp?livre $=135271 \& \& b=\mathrm{ACOR} \&$ thesaurus $=$ JURIDICO >. Acesso em: 12 jul. 2016.

BRASIL. Superior Tribunal de Justiça. REsp 1.306.687/MT, $3^{\mathrm{a}}$ T., Rel. Min. Nancy Andrighi, DJe de 22 de abril de 2014. Disponível em: <http://www.stj. jus.br/SCON/jurisprudencia/toc.jsp?livre $=$ REsp $+1306687 \& \& b=A C O R \&$ th esaurus $=$ JURIDICO $>$. Acesso em: 12 jul. 2016.

CAMPBELL, Robert J. Dicionário de Psiquiatria. 8. ed. Porto Alegre: Artmed, 2009. CARDOSO, Danilo Almeida; PINHEIRO, Jorge de Medeiros. Medidas de segurança: ressocialização e a dignidade da pessoa humana. Curitiba: Juruá, 2012.

CARRASCO GÓMEZ, Juan José. Responsabilidad médica y psiquiatria. 2. ed. Madrid: COLEX, 1998.

CASTRO, Giovana. Psicopatas do cinema: uma análise da mais perversa patologia na sétima arte. Itu, SP: FoxTablet, 2013.

CASOY, Ilana. Serial Killers Made in Brasil. Rio de Janeiro: Ediouro, 2009.

CASOY, Ilana. Serial Killer: louco ou cruel? 8. ed. São Paulo: Ediouro, 2008.

CORDÁS, TákiAthanássios; LOUZÃ NETO, Mario Rodrigues. Transtorno da personalidade: um esboço histórico conceitual. In: LOUZÃ NETO, Mario Rodrigues; CORDÁS, TákiAthanássios. Transtornos da personalidade. Porto Alegre: Livraria do Advogado, 2011.

DIAS, J. C. Cordeiro. Psiquiatria Forense. 3. ed. Lisboa: Fundação CalousteGulbenkian, 2011.

DUARTE, Nestor. Da personalidade e da capacidade. In: PELUSO, Cezar. Código Civil comentado. 10. ed. Barueri, SP: Manole, 2016.

EÇA, Antonio José. Roteiro de Psiquiatria Forense. São Paulo: Saraiva, 2010. FARIAS, Cristiano Chaves de; ROSENVAL, Nelson. Curso de Direito Civil: parte geral e LINDB. Salvador: JusPodvium, 2016.

FARIAS, Cristiano Chaves de; CUNHA, Rogério Sanches; PINTO, Ronaldo Batista. Estatuto da Pessoa com Deficiência comentado artigo por artigo. Salvador: JusPODIVM, 2016.

GARCIA, J. Alves. Psicopatologia Forense: para médicos, advogados e estudantes de Medicina e Direito. 3. ed. Rio de Janeiro: Forense, 1979.

GAUER, Gabriel José Chittó; LÜHRING, Guinter. Transtorno de personalidade antissocial e psicopatia. In: CATALDO NETO, Alfredo; GAUER, Gabriel José Chittó; FURTADO, Nina Rosa. Psiquiatria para estudantes de Medicina. 2. ed. Porto Alegre: EDIPUCRS, 2013. 
GERMÁN URDIOLA, Maria Jesús. Tratamientos involuntarios y enfermidad mental. Pamplona: [s.n.], 2012.

GOMES, Fernando Grilo; GOMES, Solange Seidl. Transtornos de personalidade: aspectos gerais. In: CATALDO NETO, Alfredo; GAUER, Gabriel José Chittó; FURTADO, Nina Rosa. Psiquiatria para estudantes de Medicina. 2. ed. Porto Alegre: EDIPUCRS, 2013.

GREGÓRIO, Ricardo A. Da curatela. In: MACHADO, Antônio Cláudio da Costa (Org.); CHINELLATO, Silmara Juny (Coord.). Código Civil interpretado: artigo por artigo, parágrafo por parágrafo. 9. ed. Barueri, SP: Manole, 2016.

HARE, Robert D. Sem consciência: o mundo perturbador dos psicopatas que vivem entre nós. Porto Alegre: Artmed, 2013.

HARE, Robert. La natureza del psicopata: algunas observaciones para entender la violencia depredadora humana. In: RAINE, Adrian; SANMARTÍN, José. Violencia y psicopatía. Barcelona: Ariel, 2000.

HARE, Robert D. Psicopatia: teoria e pesquisa. Rio de Janeiro: Livros Técnicos, 1973.

LIMA, Alcides de Mendonça. Dicionário do Código de Processo Civil. 2. ed. São Paulo: Revista dos Tribunais, 1994.

MACHADO, Antônio Cláudio da Costa. Código de Processo Civil interpretado: artigo por artigo, parágrafo por parágrafo: leis processuais civis extravagantes anotadas. Barueri, SP: Manole, 2006.

MARANHÃO, Odon Ramos. Psicologia do crime. 2. ed. São Paulo: Malheiros, 2008

MORANA, Hilda; MENDES FILHO, Ruy B. Revisão sobre transtornos da personalidade. In: MORAES, Talvane de (Org.). Ética e psiquiatria forense. Rio de Janeiro: IPUB/CUCA, 2001.

NEVES, Daniel Amorim Assumpção. Novo Código de Processo Civil comentado. Salvador: JusPodivm, 2016.

OGANIZAÇÃO MUNDIAL DA SAÚDE. Classificação de transtornos mentais e de comportamento da CID-10: descrições clínicas e diretrizes diagnósticas. Tradução Dogival Caetano. Porto Alegre: Artmed, 1993.

PACHECO, Marco Antônio et al. Internação psiquiátrica. In: CATALDO NETO, Alfredo; GAUER, Gabriel José Chittó; FURTADO, Nina Rosa (Org.). Psiquiatria para estudantes de Medicina. 2. ed. Porto Alegre: EDIPUCRS, 2013.

PALOMBA, Guido Arturo. Perícia na Psiquiatria Forense. São Paulo: Saraiva, 2016.

PALOMBA, Guido Arturo. Tratado de Psiquiatria Forense, Civil e Penal. São Paulo: Atheneu, 2003. 
REQUIÃO, Maurício. Estatuto da Pessoa com Deficiência altera o regime civil das incapacidades. 2015. Disponível em: <http://www.conjur.com. br/2015-jul-20/estatuto-pessoa-deficiencia-altera-regime-incapacidades $>$. Acesso em: 19 jun. 2016.

RODRIGUES, Rafael Garcia. A pessoa e o ser humano no Código Civil. In: TEPEDINO, Gustavo (Coord.). A parte geral do novo Código Civil: estudos na perspectiva civil- constitucional. 3. ed. Rio de Janeiro: Renovar, 2007.

SANTORO FILHO, Antonio Carlos. Direito e saúde mental. São Paulo: Verlu, 2012.

SARLET, Ingo Wolfgang. Dignidade da pessoa humana e direitos fundamentais na Constituição Federal de 1988. 9. ed. Porto Alegre: Livraria do Advogado, 2012.

TABORDA, José G. V. Responsabilidade civil do psiquiatra. In: TABORDA, José G. V.; ANDALLA-FILHO, Elias; CHALUB, Miguel. Psiquiatria Forense. 2. ed. Porto Alegre: Artmed, 2012.

TARTUCE, Flávio. O Novo CPC e o Direito Civil. 2. ed. São Paulo: Método, 2016.

TAVARES, Hermano; FERRAZ, Renata Barbosa. Transtornos da personalidade. In: MIGUEL, Eurípedes Constantino; GENTIL, Valentim; GATTAZ, Wagner Farid. Clínica Psiquiátrica. Barueri, SP: Manole, 2011. v. 1.

TRINDADE, Jorge. Manual de Psicologia Jurídica para operadores do Direito. 6. ed. Porto Alegre: Livraria do Advogado, 2012.

VANDENBOS, Gary (Org.). Dicionário de Psicologia da APA. Tradução Daniel Bueno, Maria Adriana Veríssimo Veronese, Maria Cristina Monteiro. Revisão Técnica Maria Lucia Tiellet Nunes, Giana Bitencourt Frizzo. Porto Alegre Artmed, 2010.

1 Em "O Silêncio dos Inocentes", tem-se a figura de Hannibal Lecter, um psiquiatra extremamente inteligente, que se encontra em cárcere isolado por ser um maníaco que pratica canibalismo com suas vítimas. A história é inspirada em fatos reais de psicopatia, como os de Albert Fish e Ed Gein. (CASTRO, Giovana. Psicopatas do cinema: uma análise da mais perversa patologia na sétima arte. Itu, SP: FoxTablet, 2013. p. 69,70)

2 Filme cujo enredo traz a história de um homem jovem, bonito e bem educado, que, além de fazer fortuna em Wall Street, é também um serial killer. (CASTRO, Giovana. Psicopatas do cinema: uma análise da mais perversa patologia na sétima arte. Itu, SP: FoxTablet, 2013. p. 49)

3 Nesse filme, a personagem Catherine Tramell apresenta comportamento patológico, fazendo de suas vítimas seus parceiros sexuais. Em "O Instinto Selvagem", Catherine desmitifica a ideia de que os psicopatas sejam pessoas violentas e de aparência assassina. (CASTRO, Giovana. Psicopatas do cinema: uma análise da mais perversa patologia na sétima arte. Itu, SP: FoxTablet, 2013. p. 86, 87).

4 CASOY, Ilana. Serial killer: louco ou cruel?. 8. ed. São Paulo: Ediouro, 2008, passim.

5 CASOY, Ilana. Serial killers made in Brasil. Rio de Janeiro: Ediouro, 2009, passim.

6 "A personalidade é um conjunto de características pessoais que dão sentido e significado ao modo de atuar, pensar e ser de determinada pessoa." (RICOTTA, Luiza Cristina de Azevedo. Psicologia do comportamento criminoso. Curitiba: Juruá, 2016. p. 82). 
7 CORDÁS, Táki Athanássios; LOUZÃ NETO, Mario Rodrigues. Transtorno da personalidade: um esboço histórico conceitual. In: LOUZÃ NETO, Mario Rodrigues; CORDÁS, Táki Athanássios. Transtornos da personalidade. Porto Alegre: Livraria do Advogado, 2011. p. 15.

8 GOMES, Fernando Grilo; GOMES, Solange Seidl. Transtornos de personalidade: aspectos gerais. In: CATALDO NETO, Alfredo; GAUER, Gabriel José Chittó; FURTADO, Nina Rosa. Psiquiatria para estudantes de medicina. 2. ed. Porto Alegre: EDIPUCRS, 2013. p. 559.

9 TRINDADE, Jorge. Manual de psicologia jurídica para operadores do Direito. 6. ed. Porto Alegre: Livraria do Advogado, 2012. p. 69.

10 ABDALLA-FILHO, Elias; ENGELHARDT, Wolfram. Transtornos da personalidade. In: ABDALLA-FILHO, Elias; CHALUB, Miguel; TELLES, Lisieux E. de Borda. Psiquiatria forense de Taborda. 3. ed. Porto Alegre: Artmed, 2016. p. 510.

11 Ibid., p. 506

12 MORANA, Hilda; MENDES FILHO, Ruy B. Revisão sobre transtornos da personalidade. In: MORAES, Talvane de (Org.). Ética e psiquiatria forense. Rio de Janeiro: IPUB/CUCA, 2001. p. 103.

13 DIAS, J. C. Cordeiro. Psiquiatria forense. 3. ed. Lisboa: Fundação Calouste Gulbenkian, 2011. p. 50.

14 Ibid., p. 51.

15 ABDALLA-FILHO, Elias; ENGELHARDT, Wolfram. Transtornos da personalidade. In: ABDALLA-FILHO, Elias; CHALUB, Miguel; TELLES, Lisieux E. de Borda. Psiquiatria forense de Taborda. 3. ed. Porto Alegre: Artmed, 2016. p. 511-512.

16 ORGANIZAÇÃO MUNDIAL DA SAÚDE. Classificação de transtornos mentais e de comportamento da CID-10: descrições clínicas e diretrizes diagnósticas. tradução Dogival Caetano. Porto Alegre: Artmed, 1993. p. 196.

17 AMERICAN PSYCHIATRICASSOCIATION. Manual diagnóstico e estatístico de transtornos mentais: DSM-5. Tradução Maria Inês Corrêa et al. Revisão Técnica Aristides Volpato Cordioli et al. 5. ed. Porto Alegre: Artmed, 2014. p. 645.

18 BALLONE, Geraldo José. Transtornos da personalidade. In: SOUZA, José Carlos; GUIMARÃES, Liliana A. M.; BALLONE, Geraldo José (Org.). Psicopatologia e psiquiatria básicas. 2. ed. São Paulo: Vetor, 2013. p. 105.

19 VANDENBOS, Gary (Org.). Dicionário de psicologia da APA. Tradução Daniel Bueno, Maria Adriana Veríssimo Veronese, Maria Cristina Monteiro. Revisão Técnica Maria Lucia Tiellet Nunes, Giana Bitencourt Frizzo. Porto Alegre: Artmed, 2010. p. 764.

20 CAMPBELL, Robert J. Dicionário de psiquiatria. 8. ed. Porto Alegre: Artmed, 2009. p. 611.

21 DIAS, J. C. Cordeiro. Psiquiatria forense. 3. ed. Lisboa: Fundação Calouste Gulbenkian, 2011. p. 64.

22 ABREU, Michele O. de. Da imputabilidade do psicopata. Rio de Janeiro: Lumen Juris, 2013. p. 2.

23 PALOMBA, Guido. Tratado de psiquiatria forense, civil e penal. São Paulo: Atheneu, 2003. p. 515.

24 EÇA, Antonio José. Roteiro de psiquiatria forense. São Paulo: Saraiva, 2010. p. 279.

25 PALOMBA, Guido. Tratado de psiquiatria forense, civil e penal. São Paulo: Atheneu, 2003. p. 517.

26 Ibid., p. 518.

27 HARE, Robert D. Sem consciência: o mundo perturbador dos psicopatas que vivem entre nós. Porto Alegre: Artmed, 2013. p. 42, 43.

28 HARE, Robert D. Psicopatia: teoria e pesquisa. Rio de Janeiro: Livros Técnicos, 1973. p. 4.

29 ORGANIZAÇÃO MUNDIAL DA SAÚDE. Classificação de transtornos mentais e de comportamento da CID-10: descrições clínicas e diretrizes diagnósticas. Tradução Dorgival Caetano. Porto Alegre, 1993. p. 199-200.

30 AMERICAN PSYCHIATRIC ASSOCIATION. Manual diagnóstico e estatístico de transtornos mentais: DSM-5. Tradução Maria Inês Corrêa et al. Revisão Técnica Aristides Volpato Cordioli et al. 5. ed. Porto Alegre: Artmed, 2014. p. 659.

31 BALLONE, Geraldo José. Transtornos da personalidade. In: SOUZA, José Carlos; GUIMARÃES, Liliana A. M.; BALLONE, Geraldo José (Org.). Psicopatologia e psiquiatria básicas. 2. ed. São Paulo: Vetor, 2013. p. 113.

32 AMERICAN PSYCHIATRIC ASSOCIATION. Manual diagnóstico e estatístico de transtornos mentais: DSM-5. Tradução Maria Inês Corrêa et al. Revisão Técnica Aristides Volpato Cordioli et al. 5. ed. Porto Alegre: Artmed, 2014. p. 659.

33 TAVARES, Hermano; FERRAZ, Renata Barbosa. Transtornos da personalidade. In: MIGUEL, Eurípedes Constantino; GENTIL, Valentim; GATTAZ, Wagner Farid. Clínica psiquiátrica. Barueri, SP: Manole, 2011.v. 1. p. 1055.

34 HARE, Robert. La natureza del psicopata: algunas observaciones para entender la violencia depredadora humana. In: RAINE, Adrian; SANMARTÍN, José. Violencia y psicopatía. Barcelona: Ariel, 2000. p. 17. 
35 MARANHÃO, Odon Ramos. Psicologia do crime. 2. ed. São Paulo: Malheiros, 2008. p. 79.

36 PALOMBA, Guido Arturo. Perícia na psiquiatria forense. São Paulo: Saraiva, 2016. p. 197.

37 GARCIA, J. Alves. Psicopatologia forense: para médicos, advogados e estudantes de medicina e direito. 3. ed. Rio de Janeiro: Forense, 1979. p. 204.

38 GAUER, Gabriel José Chittó; LÜHRING, Guinter. Transtorno de personalidade antissocial e psicopatia. In: CATALDO NETO, Alfredo; GAUER, Gabriel José Chittó; FURTADO, Nina Rosa. Psiquiatria para estudantes de medicina. 2. ed. Porto Alegre: EDIPUCRS, 2013. p. 608.

39 Ibid., p. 608.

40 Art. 4- A internação, em qualquer de suas modalidades, só será indicada quando os recursos extra-hospitalares se mostrarem insuficientes.

$\S 1$ O O tratamento visará, como finalidade permanente, à reinserção social do paciente em seu meio.

§ 2o O tratamento em regime de internação será estruturado de forma a oferecer assistência integral à pessoa portadora de transtornos mentais, incluindo serviços médicos, de assistência social, psicológicos, ocupacionais, de lazer e outros.

§ 3o É vedada a internação de pacientes portadores de transtornos mentais em instituições com características asilares, ou seja, aquelas desprovidas dos recursos mencionados no $§ 2-$ e que não assegurem aos pacientes os direitos enumerados no parágrafo único do art. 2․․

Art. 6o A internação psiquiátrica somente será realizada mediante laudo médico circunstanciado que caracterize os seus motivos.

Parágrafo único. São considerados os seguintes tipos de internação psiquiátrica:

I - internação voluntária: aquela que se dá com o consentimento do usuário;

II - internação involuntária: aquela que se dá sem o consentimento do usuário e a pedido de terceiro; e

III - internação compulsória: aquela determinada pela Justiça.

Art. 7ㅇ A pessoa que solicita voluntariamente sua internação ou quem a consente deve assinar, no momento da admissão, uma declaração de que optou por esse regime de tratamento.

Parágrafo único. O término da internação voluntária dar-se-á por solicitação escrita do paciente ou por determinação do médico assistente.

Art. 8o A internação voluntária ou involuntária somente será autorizada por médico devidamente registrado no Conselho Regional de Medicina - CRM do Estado em que se localize o estabelecimento. § 1 A internação psiquiátrica involuntária deverá, no prazo de setenta e duas horas, ser comunicada ao Ministério Público Estadual pelo responsável técnico do estabelecimento no qual tenha ocorrido, devendo esse mesmo procedimento ser adotado quando da respectiva alta.

§ 2o O término da internação involuntária dar-se-á por solicitação escrita do familiar, ou responsável legal, ou quando estabelecido pelo especialista responsável pelo tratamento.

Art. 9o A internação compulsória é determinada, de acordo com a legislação vigente, pelo juiz competente, que levará em conta as condições de segurança do estabelecimento, quanto à salvaguarda do paciente, dos demais internados e funcionários.

41 Art. 4 A internação, em qualquer de suas modalidades, só será indicada quando os recursos extra-hospitalares se mostrarem insuficientes.

42 HABEAS CORPUS. INTERNAÇÃO COMPULSÓRIA. LIMINAR DEFERIDA. CONFIRMAR LIMINAR GARANTINDO O DIREITO DE AGUARDAR A ELABORAÇÃO DE EXAME DE INSANIDADE MENTAL EM TRATAMENTO AMBULATORIAL. 1. A internação compulsória deve ser aplicada, primeiramente em defesa do internado e, secundariamente, da própria sociedade. Tal medida, portanto, possui caráter excepcional. 2. Ordem de Habeas Corpus concedida, confirmando-se a liminar que garantiu o direito de aguardar a elaboração de exame de insanidade mental, em tratamento ambulatorial. (TJ-DF - HBC: 20140020327313 DF 0033262-81.2014.8.07.0000, Relator: JOÃO TIMÓTEO DE OLIVEIRA, Data de Julgamento: 22/01/2015, $2^{\text {a }}$ Turma Criminal, Data de Publicação: Publicado no DJE : 27/01/2015 . Pág.: 331).

43 AGRAVO DE INSTRUMENTO - INTERNAÇÃO INVOLUNTÁRIA - TRATAMENTO PSIQUIÁTRICO - ASSISTIDO DEPENDENTE QUIIMICO - LAUDO MÉDICO CIRCUNSTANCIADO - ART. $6^{\circ}$, LEI 10.216/01 - INDICAÇÃO DA INTERNAÇÃO - AUSÊNCIA - ANTECIPAÇÃO TUTELA - REQUISITOS AUSENTES - AGRAVO DESPROVIDO. - A internação involuntária de dependente químico para tratamento psiquiátrico somente pode ser admitida quando comprovada, por laudo médico circunstanciado, sua imprescindibilidade (art. $6^{\circ}$, Lei 10.216/01) e urgência. - Inexistindo prova suficiente acerca da necessidade do assistido de submeter-se a tratamento psiquiátrico, por internação, para controle da dependência química e dos reflexos gerados pelo vício na sua vida pessoal e na sociedade, 
impossível o deferimento da antecipação dos efeitos da tutela.(TJ-MG - AI: 10210130053098002 MG, Relator: Versiani Penna, Data de Julgamento: 5/6/2014, Câmaras Cíveis / 5ª CÂMARA CÍVEL, Data de Publicação: 16/06/2014).

44 Art. 4 A internação, em qualquer de suas modalidades, só será indicada quando os recursos extra-hospitalares se mostrarem insuficientes.

$\S 1$ ㅇ $\mathrm{O}$ tratamento visará, como finalidade permanente, à reinserção social do paciente em seu meio.

45 Art. 6o-A internação psiquiátrica somente será realizada mediante laudo médico circunstanciado que caracterize os seus motivos.

Parágrafo único. São considerados os seguintes tipos de internação psiquiátrica:

I - internação voluntária: aquela que se dá com o consentimento do usuário;

II - internação involuntária: aquela que se dá sem o consentimento do usuário e a pedido de terceiro; e III - internação compulsória: aquela determinada pela Justiça.

46 Art. 7- A pessoa que solicita voluntariamente sua internação, ou que a consente, deve assinar, no momento da admissão, uma declaração de que optou por esse regime de tratamento.

47 Art. 8o A internação voluntária ou involuntária somente será autorizada por médico devidamente registrado no Conselho Regional de Medicina - CRM do Estado onde se localize o estabelecimento.

§ 1ㅇ A internação psiquiátrica involuntária deverá, no prazo de setenta e duas horas, ser comunicada ao Ministério Público Estadual pelo responsável técnico do estabelecimento no qual tenha ocorrido, devendo esse mesmo procedimento ser adotado quando da respectiva alta.

§ 2o O término da internação involuntária dar-se-á por solicitação escrita do familiar, ou responsável legal, ou quando estabelecido pelo especialista responsável pelo tratamento.

48 Art. 6o-A internação psiquiátrica somente será realizada mediante laudo médico circunstanciado que caracterize os seus motivos.

Parágrafo único. São considerados os seguintes tipos de internação psiquiátrica:

I - internação voluntária: aquela que se dá com o consentimento do usuário;

II - internação involuntária: aquela que se dá sem o consentimento do usuário e a pedido de terceiro; e III - internação compulsória: aquela determinada pela Justiça.

49 CARRASCO GÓMEZ, Juan José. Responsbilidad médica y psiquiatria. 2. ed. Madrid: COLEX, 1998. p. 239.

50 SANTORO FILHO, Antonio Carlos. Direito e saúde mental. São Paulo: Verlu, 2012. p. 36.

51 PACHECO, Marco Antônio et al. Internação psiquiátrica. In: CATALDO NETO, Alfredo; GAUER, Gabriel José Chittó; FURTADO, Nina Rosa (Org.). Psiquiatria para estudantes de medicina. 2. ed. Porto Alegre: EDIPUCRS, 2013. p. 249.

52 Ibid., p. 249.

53 NEVES, Daniel Amorim Assumpção. Novo Código de Processo Civil comentado. Salvador: JusPodivm, 2016. p. 1.176.

54 Art. 3o São absolutamente incapazes de exercer pessoalmente os atos da vida civil os menores de 16 (dezesseis) anos.

55 Art. 4o São incapazes, relativamente a certos atos ou à maneira de os exercer:

I - os maiores de dezesseis e menores de dezoito anos;

II - os ébrios habituais e os viciados em tóxico;

III - aqueles que, por causa transitória ou permanente, não puderem exprimir sua vontade;

IV - os pródigos.

Parágrafo único. A capacidade dos indígenas será regulada por legislação especial.

56 Art. 1.767. Estão sujeitos à curatela:

I - aqueles que, por causa transitória ou permanente, não puderem exprimir sua vontade;

II - (Revogado pela Lei n. 13.146, de 06.07.2015);

III - os ébrios habituais e os viciados em tóxicos;

IV - (Revogado pela Lei n. 13.146, de 06.07.2015);

$\mathrm{V}$ - os pródigos.

57 LIMA, Alcides de Mendonça. Dicionário do Código de Processo Civil. 2. ed. São Paulo: Revista dos Tribunais, 1994. p. 347.

58 Estatuto da Pessoa com Deficiência.

59 DUARTE, Nestor. Da personalidade e da capacidade. In: PELUSO, Cezar. Código civil comentado. 10. ed. Barueri, SP: Manole, 2016. p. 20.

60 FARIAS, Cristiano Chaves de; CUNHA, Rogério Sanches; PINTO, Ronaldo Batista. Estatuto da pessoa com deficiência comentado artigo por artigo. Salvador: JusPODIVM, 2016. p. 309. 
61 REQUIÃO, Maurício. Estatuto da pessoa com deficiência altera o regime civil das incapacidades. Disponível em: <http://www.conjur.com.br/2015-jul-20/estatuto-pessoa-deficiencia-altera-regime-incapacidades >. Acesso em: 19 jun. 2016.

62 FARIAS, Cristiano Chaves de; ROSENVAL, Nelson. Curso de direito civil: parte geral e LINDB. Salvador: JusPodvium, 2016. p. 349.

63 RODRIGUES, Rafael Garcia. A pessoa e o ser humano no Código Civil. In: TEPEDINO, Gustavo (Coord.). A parte geral do Novo Código Civil: estudos na perspectiva civil- constitucional. 3. ed. Rio de Janeiro: Renovar, 2007. p. 25.

64 Assim traz o CC/2002:

Art. 4o- São incapazes, relativamente a certos atos ou à maneira de os exercer:

(...)

III - aqueles que, por causa transitória ou permanente, não puderem exprimir sua vontade;

Art. 1.767. Estão sujeitos à curatela:

I - aqueles que, por causa transitória ou permanente, não puderem exprimir sua vontade;

65 Art. 4o São incapazes, relativamente a certos atos ou à maneira de os exercer:

I - os maiores de dezesseis e menores de dezoito anos;

II - os ébrios habituais e os viciados em tóxico;

III - aqueles que, por causa transitória ou permanente, não puderem exprimir sua vontade;

IV - os pródigos.

Parágrafo único. A capacidade dos indígenas será regulada por legislação especial.

66 Art. 1.767. Estão sujeitos à curatela:

I - aqueles que, por causa transitória ou permanente, não puderem exprimir sua vontade;

67 Em que pese alguns doutrinadores afirmarem ser de melhor uso o termo ação de curatela, por ser este o empregado no Estatuto da Pessoa com Deficiência (Lei n $\left.{ }^{\circ} 13.146 / 2015\right)$, bem como por ter a expressão interdição um caráter pejorativo, adotar-se-á, aqui, ação de interdição, por ser esta a terminologia utilizada pelo Código de Processo Civil em vigor.

68 FARIAS, Cristiano Chaves de; ROSENVALD, Nelson. Curso de direito civil: parte geral e LINDB. 14. ed. Salvador, 2016. p. 350.

69 Art. 747. A interdição pode ser promovida:

I - pelo cônjuge ou companheiro;

II - pelos parentes ou tutores;

III - pelo representante da entidade em que se encontra abrigado o interditando;

IV - pelo Ministério Público.

70 HABEAS CORPUS. PROCESSO CIVIL DE INTERDIÇÃO. INTERNAÇÃO JUDICIAL. ENFERMIDADE MENTAL. TRANSTORNO DE PERSONALIDADE ANTISSOCIAL (TPAS). LAUDO PERICIAL. INTERNAÇÃO RECOMENDADA. 1.- É admitida, com fundamento na Lei 10.216/01, em processo de interdição, da competência do Juízo Cível, a determinação judicial da internação psiquiátrica compulsória do enfermo mental perigoso à convivência social, assim reconhecido por laudo técnico pericial, que conclui pela necessidade da internação. Legalidade da internação psiquiátrica compulsória. Observância da Lei Federal n.10.216/01 e do Decreto Estadual n. 53.427/0.8, relativo à aludida internação em Unidade Experimental de Saúde.

2.- A anterior submissão da medida socioeducativa restritiva da liberdade, devido ao cometimento de infração, correspondente a tipo penal, não obsta a determinação da internação psiquiátrica compulsória após o cumprimento da medida socioeducativa. Homicídios cometidos com perversidade de agressão e afogamento em poça d'água contra duas crianças, uma menina de 8 anos e seu irmão, de 5 anos, para acobertar ataque sexual contra elas. 3.- Laudos que apontam o paciente como portador de Transtorno de Personalidade Antissocial (TPAS) - (dissocial - CID. F60.2): "Denota agressividade latente e manifesta, pouca capacidade para tolerar contrariedade e/ou frustrações, colocando suas necessidades e desejos imediatos pessoais acima das normas, regras e da coletividade, descaso aos valores éticos, morais , sociais ou valorização da vida humana, incapacidade de sentir e demonstrar culpa ou arrependimento. Características compatíveis com transtorno de personalidade sociopática aliada à limitação intelectual, podendo apresentar, a qualquer momento, reações anormais com consequências gravíssimas na mesma magnitude dos atos infracionais praticados, sendo indicado tratamento psiquiátrico e psicológico em medida de contenção". 4.- O presente julgamento, no âmbito da $3^{a}$ Turma, harmoniza a jurisprudência de ambas as Turmas da $2^{\text {a }}$ Seção desta Corte, na mesma orientação do HC 169.172-SP, Rel. Min. LUIS FELIPE SALOMÃO, em caso de grande repercussão nacional, no sentido de que "a internação 
em qualquer de suas modalidades, só será iniciada quando os recursos extra-hospitalares se mostrarem insuficiente". Tal dispositivo contém ressalva em sua parte final, dispensando a aplicação dos recursos extra-hospitalares se houver demonstração efetiva da insuficiência de tais medidas.[...] A internação compulsória em sede de ação de interdição, como é o caso dos autos, não tem caráter penal, não devendo ser comparada à medida de segurança ou à medida socioeducativa a que esteve submetido no passado o paciente em face do cometimento de ato infracional análogo a homicídio e estupro. Não se ambiciona nos presentes autos aplicar sanção ao ora paciente, seja na espécie de pena, seja na forma de medida de segurança”. 5.- Legalidade da internação psiquiátrica compulsória. Determinação de reavaliação periódica. 6.- Denegada a ordem de Habeas Corpus, com observação. (STJ, HC 135271 / SP, $3^{\mathrm{a}}$ T., Rel. Min. SidneiBeneti, DJe 4/2/2014).

71 Art. 748. O Ministério Público só promoverá interdição em caso de doença mental grave:

I - se as pessoas designadas nos incisos I, II e III do art. 747 não existirem ou não promoverem a interdição; II - se, existindo, forem incapazes as pessoas mencionadas nos incisos I e II do art. 747.

72 Art. 747. A interdição pode ser promovida:

I - pelo cônjuge ou companheiro;

II - pelos parentes ou tutores;

III - pelo representante da entidade em que se encontra abrigado o interditando;

IV - pelo Ministério Público.

Parágrafo único. A legitimidade deverá ser comprovada por documentação que acompanhe a petição inicial.

73 Art. 1.178. O órgão do Ministério Público só requererá a interdição:

I - no caso de anomalia psíquica;

II - se não existir ou não promover a interdição algumas das pessoas designadas no artigo antecedente, ns. I e II;

III - se, existindo, forem menores ou incapazes.

74 Art. 1.177. A interdição pode ser promovida:

I - pelo pai, mãe ou tutor;

II - pelo cônjuge ou algum parente próximo;

III - pelo órgão do Ministério Público.

75 Art. 1.767. Estão sujeitos à curatela:

I - aqueles que, por enfermidade ou deficiência mental, não tiverem o necessário discernimento para os atos da vida civil.

76 MACHADO, Antônio Cláudio da Costa. Código de Processo Civil interpretado: artigo por artigo, parágrafo por parágrafo: leis processuais civis extravagantes anotadas. Barueri, SP: Manole, 2006. p. 1.755 .

77 ABREU, Célia Barbosa. Primeiras linhas sobre interdição após o Novo Código de Processo Civil. Itu, SP: CRV, 2015. p. 173.

78 A complexidade envolta à definição de doença mental, no tocante ao "normal" e ao "patológico", mostra-se mais evidente com as alterações ocorridas no sistema de classificação da Associação Americana de Psiquiatria (APA), firmada pelo Diagnostic and Statistical Manual of Mental Desorders (DSM), cuja $1^{\text {a }}$ edição, de 1952, trazia 160 perturbações. A quarta versão, DSM-IV, de 1994, aponta 410. A mais recente versão do manual, o DSM-V, de maio de 2013 , cataloga 450 novas categorias diagnósticas.

79 GERMÁN URDIOLA, Maria Jesús. Tratamientos involuntarios y enfermidad mental. Pamplona: [s.n.], 2012. p. 59.

80 Art. $1^{\circ}$ A República Federativa do Brasil, formada pela união indissolúvel dos Estados e Municípios e do Distrito Federal, constitui-se em Estado Democrático de Direito e tem como fundamentos:

$[\ldots]$

III - a dignidade da pessoa humana;

81 Art. $3^{\circ}$ Constituem objetivos fundamentais da República Federativa do Brasil:

$[\ldots]$

III - erradicar a pobreza e a marginalização e reduzir as desigualdades sociais e regionais;

82 Art. $5^{\circ}$ Todos são iguais perante a lei, sem distinção de qualquer natureza, garantindo-se aos brasileiros e aos estrangeiros residentes no País a inviolabilidade do direito à vida, à liberdade, à igualdade, à segurança $\mathrm{e}$ à propriedade, nos termos seguintes:

[...] 
$\S 2^{\circ}$ Os direitos e garantias expressos nesta Constituição não excluem outros decorrentes do regime e dos princípios por ela adotados, ou dos tratados internacionais em que a República Federativa do Brasil seja parte.

83 ABREU, Célia Barbosa. Primeiras linhas sobre a interdição após o Novo Código de Processo Civil. Curitiba: CRV, 2015. p. 32.

84 Ibid., p. 148.

85 SARLET, Ingo Wolfgang. Dignidade da pessoa humana e direitos fundamentais na Constituição Federal de 1988. 9. ed. Porto Alegre: Livraria do Advogado, 2012. p. 56.

86 TABORDA, José G. V. Responsabilidade civil do psiquiatra. In: TABORDA, José G. V.; ANDALLA-FILHO, Elias; CHALUB, Miguel. Psiquiatria forense. 2. ed. Porto Alegre: Artmed, 2012. p. 284.

87 CARDOSO, Danilo Almeida; PINHEIRO, Jorge de Medeiros. Medidas de segurança: ressocialização e a dignidade da pessoa humana. Curitiba: Juruá, 2012. p. 19.

88 FARIAS, Cristiano Chaves de; ROSENVALD, Nelson. Curso de direito civil: parte geral e LINDB. 14. ed. Salvador, 2016. p. 348.

89 Ibid., p. 348.

90 Art. 1.767. Estão sujeitos à curatela:

I - aqueles que, por causa transitória ou permanente, não puderem exprimir sua vontade;

II - (Revogado);

III - os ébrios habituais e os viciados em tóxico;

91 PALOMBA, Guido Arturo. Tratado de psiquiatria forense civil e penal. São Paulo: Atheneu, 2003. p. 532.

92 GREGÓRIO, Ricardo A. Da curatela. In: MACHADO, Antônio Cláudio da Costa (Org.); CHINELLATO, Silmara Juny (Coord.). Código civil interpretado: artigo por artigo, parágrafo por parágrafo. 9. ed. Barueri, SP: Manole, 2016. p. 1.566.

93 ABREU, Célia Barbosa. Primeiras linhas sobre o processo de interdição após o Novo Código de Processo Civil. Curitiba: CRV, 2015. p. 37.

94 Flávio Tartuce se manifesta no sentido contrário, com o entendimento de que o psicopata deve ser considerado plenamente capaz para o Direito Civil, precipuamente para os atos existenciais familiares. Para o autor, não há como enquadrar o psicopata entre os relativamente capazes, não estando, portanto, sujeito à medida de interdição. (TARTUCE, Flávio. O Novo CPC e o Direito Civil. 2. ed. São Paulo: Método, 2016. p. 477- 478).

95 Art. 1.767. Estão sujeitos à curatela:

I - aqueles que, por enfermidade ou deficiência mental, não tiverem o necessário discernimento para os atos da vida civil;

II - aqueles que, por outra causa duradoura, não puderem exprimir sua vontade;

III - os deficientes mentais, os ébrios habituais e os viciados em tóxico;

IV - os excepcionais, sem desenvolvimento mental completo.

96 ABREU, Célia Barbosa; VAL, Eduardo Manuel. A flexibilização da curatela do psicopata: uma interpretação constitucional pelo Superior Tribunal de Justiça. Revista da Ajuris, Porto Alegre, v. 41, n. 134, p. 120-121, jun. 2014.

97 Constatou-se que a situação do psicopata não se enquadrava ente as previstas no art. 1.767, I, do CC/2002, com redação anterior à dada pela Lei n. 13.146/2015. A redação do dispositivo legal preconizava que estavam sujeitos à curatela aqueles que, por enfermidade ou deficiência mental, não tiverem o necessário discernimento para os atos da vida civil.

98 BRASIL. Superior Tribunal de Justiça. REsp 1.306.687/MT, $3^{\text {a }}$ T., Rel. Min. Nancy Andrighi, DJe 22/04/2014. Disponível em: <http://www.stj.jus.br/SCON/jurisprudencia/toc.jsp?livre=REsp+13066 $87 \& \& b=$ ACOR \& thesaurus $=$ JURIDICO $>$. Acesso em: 12 jul. 2016.

99 Conquanto haja autores que tenham o entendimento de que a psicopatia figura entre os transtornos mentais que levam à interdição relativa, a decisão do STJ, ao se manifestar pela internação compulsória do psicopata, é no sentido de que a interdição é total.

100 Oportuno lembrar manifestações doutrinária no sentido de que a reincidência não é determinada pelo tipo de crime, mas sim pela análise da personalidade do indivíduo. (MORANA, Hilda; MENDES FILHO, Ruy B. Revisão sobre transtornos da personalidade. In: MORAES, Talvane de (Org.). Ética e psiquiatria forense. Rio de Janeiro: IPUB/CUCA, 2001. p. 117).

101 Art. 1.767, III, com redação anterior à Lei n. 13.146/2015.

102 BRASIL. Superior Tribunal de Justiça. REsp 1.306.687/MT, $3^{a}$ T., Rel. Min. Nancy Andrighi, DJe 
22/04/2014. Disponível em: <http://www.stj.jus.br/SCON/jurisprudencia/toc.jsp?livre=REsp+13066 $87 \& \& b=$ ACOR \& thesaurus=JURIDICO $>$. Acesso em: 12 jul. 2016.

103 Guido Palomba lista a psicopatia (condutopatia) entre as perturbações da saúde mental sujeitas à interdição relativa. (PALOMBA, Guido Arturo. Perícia na psiquiatria forense. São Paulo: Saraiva, 2016. p. 68).

104 BRASIL. Superior Tribunal de Justiça. REsp 1.306.687/MT, 3ª T., Rel. Min. Nancy Andrighi, DJe 22/4/2014. Disponível em: <http://www.stj.jus.br/SCON/jurisprudencia/toc.jsp?livre=REsp+130668 $7 \& \& b=A C O R \&$ thesaurus $=J U R I D I C O>$. Acesso em: 12 jul. 2016.

105 FARIAS, Cristiano Chaves de; ROSENVALD, Nelson. Curso de direito civil: parte geral e LINDB. 14. ed. Salvador, 2016. p. 351.

106 Art. 1.767. Estão sujeitos à curatela:

I - aqueles que, por enfermidade ou deficiência mental, não tiverem o necessário discernimento para os atos da vida civil;

107 ABREU, Célia Barbosa; VAL, Eduardo Manuel. A flexibilização da curatela para o psicopata: uma interpretação constitucional pelo Superior Tribunal de Justiça. Revista da Ajuris, Porto Alegre, v. 41, n. 41, p. 126, jun. 2014.

108 Art. 4ํA internação, em qualquer de suas modalidades, só será indicada quando os recursos extra-hospitalares se mostrarem insuficientes.

109 ABREU, Célia Barbosa. Primeiras linhas sobre a interdição após o Novo Código de Processo Civil. Curitiba: CRV, 2015. p. 162.

C O M P U L S R Y P S Y C H I A T R I C HOSPITALIZATION OF PSYCHOPATHS IN INTERDICTION PROCEEDINGS: AN INTERDISCIPLINARY STUDY BETWEEN PSYCHIATRY, PSYCHOLOGY AND PROCEDURAL LAW

\begin{abstract}
The current study aims at making a few observations about injunction proceedings in compulsory psychiatric hospitalization of psychopaths. Such study has proven to be relevant to both law practitioners in general and also to other fields of human knowledge, such as Medicine and Sociology. Although not expressly provided for in the legal system, the possibility of hospitalization by court order in interdiction proceedings, in cases of psychopathy, must have its suitability checked by a systematic interpretation, according to the peculiarities of each case, based upon the principle of human dignity.

Keywords: Psychopathy. Compulsory psychiatric hospitalization. Interdiction proceedings. Continence between orders.
\end{abstract}

Submetido: 8 ago. 2016

Aprovado: 28 out. 2016 